\title{
La Comédie des proverbes, texte établi et annoté par Michael Kramer
}

\section{Chiara Rolla}

\section{(2) OpenEdition}

1 Journals

\section{Edizione digitale}

URL: https://journals.openedition.org/studifrancesi/39211

DOI: 10.4000/studifrancesi.39211

ISSN: 2421-5856

\section{Editore}

Rosenberg \& Sellier

\section{Edizione cartacea}

Data di pubblicazione: 1 décembre 2004

Paginazione: 357

ISSN: 0039-2944

\section{Notizia bibliografica digitale}

Chiara Rolla, «La Comédie des proverbes, texte établi et annoté par Michael Kramer», Studi Francesi [Online], 143 (XLVIII | II) | 2004, online dal 30 novembre 2015, consultato il 19 mai 2021. URL: http:// journals.openedition.org/studifrancesi/39211 ; DOI: https://doi.org/10.4000/studifrancesi.39211

Questo documento è stato generato automaticamente il 19 mai 2021.

\section{(c) $($ i) $(9)$}

Studi Francesi è distribuita con Licenza Creative Commons Attribuzione - Non commerciale - Non opere derivate 4.0 Internazionale. 


\title{
La Comédie des proverbes, texte établi et annoté par Michael Kramer
}

\author{
Chiara Rolla
}

\section{NOTIZIA}

La Comédie des proverbes, texte établi et annoté par MICHAEL KRAMER, Genève, Droz, 2003, $484 \mathrm{p}$.

1 Esce, nella collezione «Textes littéraires français», questa dottissima edizione critica della Comédie des proverbes. Nell'Introduzione, già di per sé un ricco saggio, Kramer ripercorre e ricostruisce dettagliatamente la storia e le vicissitudini della pièce, descrivendone le numerose edizioni che videro la luce nel corso del XVII secolo, studiandone la lingua e la drammaturgia, e, trattandosi di opera anonima, affrontando l'annoso problema della datazione e dell'attribuzione.

2 Il testo presentato riproduce l'edizione del 1633 e, entro limiti ragionevoli, è rimasto il più possibile fedele all'originale.

3 Il volume è corredato da una ricca bibliografia critica e da un apparato lessicografico comprendente un repertorio fraseologico, utile a mettere in luce il legame che intercorre tra la Comédie des proverbes et les Curiositez françoises di Antoine Oudin, un indice ragionato delle parole chiave della pièce, dei commenti al testo ed un glossario. 